\title{
Determination of Nutritional Composition of Ackee's Apple Blighia sapida and Monkey Kola Cola millenii
}

\author{
Oyetade Joshua Akinropo ${ }^{1}$, Bello Lukman Abidemi $^{2}$ and Adesiyan Blessing \\ Adedayo $^{3}$ \\ ${ }^{1}$ Department of Chemistry, Federal University of Technology, Akure, Ondo State, Nigeria \\ e-mail: joshuaoyetade@gmail.com \\ ${ }^{2}$ Department of Chemistry, Federal University of Technology, Akure, Ondo State, Nigeria \\ e-mail: belloabidemi@gmail.com \\ ${ }^{3}$ Department of Chemistry, Obafemi Awolowo, University Ile-Ife, Osun State, Nigeria. \\ e-mail: adesiyanblessing@gmail.com
}

\begin{abstract}
The proximate analysis of the fruit sample that homogenously sampled from the wild was taken and quartered to get appreciable weight fit for analysis. Due to it perishable nature the quartered sample for each of the fruit was stored in an air tight container and kept in the refrigerator at a temperature of about $4^{\circ} \mathrm{C}$. For the determination of the nutritional composition, parameters which include their proximate, minerals, and vitamin $\mathrm{C}$ were quantitatively determined while the anti-nutrient composition were qualitatively and quantitatively analyzed. Compared to ackee's apple, monkey cola was found to consist of $64.41 \%$ moisture content, $1.69 \%$ ash, $10.21 \%$ crude fibre, $1.25 \%$ crude fat, $4.44 \%$ crude fibre, $18.06 \%$ carbohydrates while ackee's apple consist of $73.21 \%$ moisture, $1.49 \%$ ash, $9.38 \%$ crude protein, $13.98 \%$ crude fat, $2.08 \%$ crude fibre, $0.86 \%$ carbohydrates and $4.45 \%$ of vitamin C. The mineral analysis for both samples was quantitatively determined using Atomic Absorption spectrophotometer (AAS). The minerals determined for ackee's apple and monkey cola were magnesium which was $1391.65 \mathrm{ppm}$, calcium $628.23 \mathrm{ppm}$, sodium $506.96 \mathrm{ppm}$, potassium $3976.14 \mathrm{ppm}$, iron $1.0 \mathrm{ppm}$, copper 5.00, zinc 4.00, cobalt 3.0 and phosphorus $2616.90 \mathrm{ppm}$ the iron however, was not detected. Ackee's apple on the other hand, consist of magnesium $498.01 \mathrm{ppm}$, calcium 478.56 ppm, sodium $398.80 \mathrm{ppm}$, potassium $4970.18 \mathrm{ppm}$, copper 2.00, zinc 5.00, cobalt 3.0 and
\end{abstract}

Received: October 29, 2020; Accepted: December 1, 2020

Keywords and phrases: Ackee's apple, Monkey kola, proximate, minerals, anti-nutrients.

Copyright (C) 2021 Oyetade Joshua Akinropo et al. This is an open access article distributed under the Creative Commons Attribution License, which permits unrestricted use, distribution, and reproduction in any medium, provided the original work is properly cited. 
phosphorus $373.84 \mathrm{ppm}$. The qualitative screening of the anti-nutrients revealed the absence of phenol from both fruit samples while tannins were present only in the monkey cola. The flavonoids, phytic acid and oxalate were quantitatively determined to be 1240 $\mathrm{mg}, 625 \mathrm{mg}$ and $155 \mathrm{mg}$ for Monkey kola and $640 \mathrm{mg}, 340 \mathrm{mg}$ and $65 \mathrm{mg}$ for Ackee's apple.

\section{Introduction}

Plants and animals have been an interesting source of food with nutritional and pharmacological benefits (Ross [1], Anhawange et al. [2]). In addition to this, effective hormonal coordination and nutritional health of man is mostly a function of plant foods. Foods derived from plants are vital components of the dietary food formulated for adults and infants. This is because almost all essential mineral and organic nutrients to humans are either directly or indirectly absorbed into the body upon consumption, digestion and ingestion of plant based food (Ekué et al. [3]). Biologically, plants are autotrophic in nature and nutrients derived from them are classed as macro- or micronutrients (Gibney et al. [4], Gibson [5]). Research reveals that most fruit samples in the wild life provide carbohydrates, water-soluble vitamins, various carotenoids and certain minerals essential for the body. Furthermore, these fruits consist of phytochemicals with appreciable pharmacological attributes (Lanham-New et al. [6], Gandy [7]). These phytochemicals includes: flavonoids, flavones, phytosterols, phenols and polyphenols, phytoestrogens, glucosinolates, etc. Malnutrition arises from low consumption or insufficient consumption of these nutrients (Tulchinsky and Varavikova [8]). Inadequate amount of nutrient intake result into malnutrition and predispose individuals to disabilities, diseases and various hormonal dysfunctions (Friedrich [9], Arthur [10]).

Over the years, little attention has been directed towards the study of nutritional composition of the Monkey kola (Cola millenii) Ackee's apple (Blighia sapida) fruit as source of remedial nutrient supplements to tackle malnutrition. Ackee's apple tree is a fruit tree from Guinean forests of West Africa, where it is noted particularly for its medicinal and aesthetic values. Monkey kola on the other hand, is a wild plant of tropical and sub-tropical countries whose place of origin was probably supposed to be from Indonesia (Mitchell [11]). Cola millenii belong to the Sterculiaceae family, genus Cola and species millenii. Cola millenii is edible fruit of varying characteristics of sweetness. It is widely distributed throughout tropical Africa, from Senegal to Cameroon. It is common in southern part of Nigeria, where they are eaten as edible fruits by peasant farmers during the peak season. Descriptively, its features come either as shrub or tree up 
to 7-12 $\mathrm{m}$ high, somewhat twisted and branchy, with rounded and open crown. The bark is thin, washed pale brown, peeling off in thin (Orisake and Olugbade [12]). These fruits under study especially the ackee fruit aril, is edible and can be eaten fresh, dried, fried, boiled, roasted or made into sauce or soup. In Benin City of Nigeria, the dried ackee's arils and ackee's soap, made from the ash of fruit pods and seeds, are traded in local markets providing substantial revenue to farmers and traders who are mostly women (Atolani et al. [13]). To ensure an adequate dietary intake of all essential nutrients in food formulation using this underutilized fruit samples in the wild, this article aim at investigating various nutritional composition and the anti-nutrient constituents of each fruit samples.

\section{Materials and Methods}

\subsection{Sample Collection and Preparation}

The wild fruit samples were collected fresh from five different trees grown in Archive's University Owo, Ondo state Nigeria. Both fruit samples collected were identified by the department of crop soil and pest management at the Federal University of Technology Akure. Prior to analysis, the fruit samples were separately chopped with stainless steel knife into tiny pieces, pulverized and stored in the fridge at $4{ }^{\circ} \mathrm{C}$ until further analysis. Portion of the pulverized samples were sundried for a week and kept in the fridge in other to carry out their anti-nutrients composition.

\subsection{Methods}

\section{Nutritional composition}

\section{Proximate Analysis}

Methods of the Association of Official Analytical Chemists (AOAC [14]) were used for the determination of crude protein, moisture, crude fibre, and fat contents of the samples. These analysis were carried out in triplicate. The proximate values of each parameter were reported in percentage. The determination of ash content was done by ashing at $550^{\circ} \mathrm{C}$ for 3 hours. However, the determination of the crude protein was done through the Kjeldah method (AOAC [14]). The nitrogen value resulting from the experimental and mathematical calculation was multiply with a conversion factor (6.25). The crude fibre content of the samples was determined by digestion method and the lipid content was determined by Soxhlet extraction method (AOAC [14]). Total soluble carbohydrate was determined by the difference of the sum of all the proximate 
compositions from 100\% (AOAC [14], Pearson [15], Onyeike and Osuji [16]). While the Vitamin $\mathrm{C}$ was analyzed as described by Benderitter et al. [17].

\section{Mineral Analysis}

Mineral contents of Monkey kola and Ackee's apple: $\mathrm{Ca}, \mathrm{Mg}, \mathrm{K}, \mathrm{Na}, \mathrm{Fe}, \mathrm{Zn}, \mathrm{Mn}$ and $\mathrm{Cu}$ were determined using the atomic absorption spectrophotometer (AAS-Buck 205), as described by the methods of the Association of Official Analytical Chemists (AOAC [18]). Phosphorus was determined calorimetrically as described by AOAC [18]. The values of calcium, magnesium and potassium were reported in percentage while sodium, iron, zinc, phosphorus, manganese and copper were reported in parts per million (ppm).

\section{Phytochemical Analysis}

Phytochemical analysis includes the determination of phenol, saponin, alkaloids and flavonoids. All of these were determined based on methods of analysis described by AOAC [18].

\section{Results and Discussion}

\section{Proximate, Vitamin and Mineral Analysis}

Table 1 shows the proximate analysis of both fruit samples with their vitamin C content. While the Table 2 shows the mineral analysis of both fruit samples under study. The wild fruit samples (Monkey kola and Ackee's apple) consist of $64.35 \%$ and $73.21 \%$ of moisture content respectively. Inference can drawn based on their percentage moisture content that the fruit samples are perishable via microbial and biochemical activities (Guisseppe and Baratta [19]). Monkey kola was also observed to contain high amount of calorific energy of $18.06 \%$ unlike the Ackee which has a low content of carbohydrate of about $0.86 \%$. The high carbohydrate content of Monkey kola shows it to be a good source of energy, which is also confirmed by Voet et al. [20]. However when compared with Garcina Kola (belonging to the same family) and sorghum studied by Adetuyi and Akpambang [21], the carbohydrate content of Monkey kola shows higher value. Furthermore, the percentage of the crude protein of Monkey kola and Ackee's apple are $10.21 \pm 0.02$ and $9.38 \pm 0.01$ respectively. The results of their crude protein content are higher when compared with the nutritional analysis carried out by Jacskon [22]. Voet et al. [20], reveals that nitrogen containing natural product are often referred to as protein which is essential for the survival and healthy living of humans and animals. The high content of protein for both fruit samples is essential in food formulation because, it 
facilitates the build-up and repair of worn out tissues from infants and adults (Gibney et al. [4], Gibson [5]). However their vitamin C content is higher when compared to vitamin content investigated by Imoru et al. [23].

Table 1. Proximate and Vitamin C composition of Monkey kola (Cola millenii) and Ackee (Blighia sapida)

Parameters
Monkey kola (Cola

Millenii)

\begin{tabular}{ccc}
\hline Moisture content (\%) & $64.41+0.06$ & $73.21 \pm 0.01$ \\
\hline Ash (\%) & $1.69 \pm 0.00$ & $1.49 \pm 0.09$ \\
\hline Crude protein (\%) & $10.21 \pm 0.02$ & $9.38 \pm 0.01$ \\
\hline Crude Fat (\%) & $1.25 \pm 0.03$ & $13.98 \pm 0.02$ \\
\hline Crude Fiber (\%) & $4.44 \pm 0.01$ & $2.08 \pm 0.05$ \\
\hline Carbohydrates (\%) & $18.06 \pm 0.10$ & $0.86 \pm 0.10$ \\
\hline Vitamin C (\%) & $6.45 \pm 0.02$ & $4.45 \pm 0.10$ \\
\hline
\end{tabular}

Table 2. Mineral Composition of Monkey kola (Cola millenii) and Ackee (Blighia sapida)

\begin{tabular}{ccc}
\hline Parameters & $\begin{array}{c}\text { Monkey kola }(\text { Cola } \\
\text { Millenii) }(\mathbf{p p m})\end{array}$ & $\begin{array}{c}\text { Ackee (Blighia Sapida) } \\
(\mathbf{p p m})\end{array}$ \\
\hline Magnesium $(\mathrm{Mg})$ & 1391.65 & 498.01 \\
\hline Calcium $(\mathrm{Ca})$ & 628.23 & 478.56 \\
\hline Sodium $(\mathrm{Na})$ & 506.96 & 398.80 \\
\hline Potassium (K) & 3976.14 & 4970.18 \\
Iron (Fe) & $\mathrm{ND}$ & 1.0 \\
Copper & 5.00 & 2.00 \\
Zinc & 4.00 & 5.00 \\
Cobalt & 3.0 & 3.0 \\
\hline Phosphorus & 2616.90 & 373.84 \\
\hline
\end{tabular}


In addition to their proximate value, the mineral composition from Table 2 for the samples shows that that both fruit contains high content of body building metals which enhances growth, development and proper formation of the body tissues and bone growth. The highest mineral content for Ackee's apple and Monkey kola is potassium, having $4970.18 \mathrm{ppm}$ and $3976.14 \mathrm{ppm}$. Hence, fruits samples with this significant value of minerals enhances blood clothing, prevention of paralysis and strengthened the body muscles (Latunde-dada [24]). Other essential mineral which are present in appreciable amount are Magnesium, Calcium and sodium having a value of 1391.65, 628.23 and 506.96 for Monkey kola and 498.01, 478.56 and 398.80 for Ackee's apple. These minerals are essential for controlling of skeletal and muscles contraction and relaxation and high amount of calcium enhances bone and teeth growth (Kumbarawa et al. [25]).

Most of this minerals are required daily however, in trace amount (RDA $<200$ $\mathrm{mg} /$ day), due to their vital roles in enzymatic activities, minerals such as cobalt (biosynthesis of vitamin B12 co-enzymes); copper (redox enzymes including cytochrome c oxidase); iron (range of enzymes, hemoglobin and other proteins); manganese (processing of oxygen); zinc (enzymes such as dehydrogenase) etc. It is worthy of note to add that the deficient or excess intakes of minerals can trigger severe health consequences (Gibney et al. [4], Lanham-New et al. [6], Heaney [26]).

\section{Qualitative and Quantitative Phytochemical Composition of the Monkey kola (Cola millenii) and Ackee (Blighia sapida)}

Table 3 shows the qualitative test (alkaloid, saponin, tannin, cardiac glycoside, sterol, phenol and flavonoid) carried out on fruit samples under study. The Table indicated the presence of these phytochemicals except for the absence of phenol in both samples and the presence of tannins only in Kola millenii. Table 4 shows the quantitative analysis carried out on some selected anti-nutrient components (flavoniods, Phytic acid and Oxalate) of the fruit samples. The Table reveals that Kola millenii quantitatively consist of higher amount of flavonoids $(1240 \mathrm{mg})$, phytic acid $(625 \mathrm{mg})$, oxalate $(155 \mathrm{mg})$ than Blighia sapida which consist of flavonoids $(640 \mathrm{mg})$, phytic acid $(340 \mathrm{mg})$, oxalate (65 mg). Studies carried out by Abdullahi [27], Gills [28] and Ikpema [29] reveal that the presence of these anti-nutrients indicates the pharmacological benefits of these fruit samples. Saponins are a special class of glycosides which have soapy characteristics and active anti-fungal activity while tannins are equally known for its anti-microbial activities. They are water soluble plant polyphenols that precipitate proteins (Prasad et al. [30]). However, it is worthy of note to add that the present of these natural products 
(flavoniods, Phytic acid and Oxalate) in appreciable amount as stated in Table 4, can enhance the treatment of some intestinal disorder, possesses significant anti-oxidizing activities which forestalls the generation and the activities of reactive oxygen species (ROS) that causes various mutagenic and neurological disorder (Boham et al. [31], Okwu and Josiah [32], Ayoola [33]).

Table 3. Qualitative test on the anti-nutrient carried out on Monkey kola (Cola millenii) and Ackee (Blighia sapida)

\section{Test}

Monkey kola (Cola

Millenii)
Ackee (Blighia

sapida)

\begin{tabular}{ccc}
\hline Detection of Flavonoids & + & + \\
Cardiac Glycosides & + & + \\
Detection of Alkaloids & + & + \\
\hline Detection of Saponins & + & - \\
Detection of Tannins & + & - \\
\hline Detection of Phenol & - & + \\
\hline
\end{tabular}

Table 4. Result of quantitative test of anti-nutrient carried out on Monkey kola (Cola millenii) and Ackee (Blighia sapida)

\begin{tabular}{ccc}
\hline Test & $\begin{array}{c}\text { Monkey kola }(\text { Cola } \\
\text { Millenii })(\boldsymbol{m g})\end{array}$ & $\begin{array}{c}\text { Ackee }(\text { Blighia sapida }) \\
(\boldsymbol{m g})\end{array}$ \\
\hline Flavonoids & 1240 & 640 \\
Phytic Acid & 625 & 340 \\
Oxalate & 155 & 65 \\
\hline
\end{tabular}

\section{Conclusion}

The study of Monkey kola and Ackee's apple fruit expressly reveal its perishable nature due to it high moisture content however, easily digestible into the body. It also indicates the body building function due to the significant amount of protein content present in both fruit samples. Their mineral constituents value (especially the magnesium, potassium and phosphorus) offers a remedial benefit in tackling malnutrition as a result of lack of needful minerals in the body. The incorporation of these fruit samples will be a 
major aid for the supply of needful minerals to the bodies via its intake in food formulation for optimum enzymatic functionality. Furthermore, the pharmacological benefits from quantitative and qualitative study of their anti-nutrients shows that monkey kola to have appreciable medicinal benefit over Ackee's apple

\section{References}

[1] M.D. Ross and W.T. Jones, A genetic polymorphism for tannin production in Lotus corniculatus and its relationship to cyanide polymorphism, Theoret. Appl. Genetics 64 (1983), 263-268. https://doi.org/10.1007/BF00303776

[2] B.A. Anhwange, V.O. Ajibola and S.J. Oniye, Chemical studies of the seeds of Moringa oleifera (Lam) and Detarium microcarpum (Guill and Sperr), J. Biol. Sci. 4(6) (2004), 711-715. https://doi.org/10.3923/jbs.2004.711.715

[3] M.R. Ekué, B. Sinsin, O. Eyog-Matig and R. Finkeldey, Uses, traditional management, perception of variation and preferences in ackee (Blighia sapida K.D. Koenig) fruit traits in Benin: implications for domestication and conservation, J. Ethnobiology Ethnomedicine 6 (2010), Article No. 12. https://doi.org/10.1186/1746-4269-6-12

[4] M.J. Gibney, S.A. Lanham-New, A. Cassidy and H.H. Vorster, (eds.), Introduction to Human Nutrition (The Nutrition Society Textbook), 2nd ed., Wiley-Blackwell, 2009.

[5] R.S. Gibson, (ed.), Principles of Nutritional Assessment, OUP, USA, 2005.

[6] S. A. Lanham-New, I. A. MacDonald and H. M. Roche, (eds.), Nutrition and Metabolism (The Nutrition Society Textbook), 2nd ed., Wiley-Blackwell, 2010. https://doi.org/10.1002/9781444327779

[7] J. Gandy, (Ed.), Manual of Dietetic Practice, 5th ed., Wiley-Blackwell, 2014

[8] T.H. Tulchinsky and E.A. Varavikova, The New Public Health: An Introduction for the 21st Century, Academic Press, 2014.

[9] M.J. Friedrich, Assessing and addressing global malnutrition, JAMA 313(3) (2015), 235. https://doi.org/10.1001/jama.2014.18329

[10] S.S. Arthur, B. Nyide, A. B. Soura, K. Kahn, M. Weston and O. Sankoh, Tackling malnutrition: a systematic review of 15 -year research evidence from INDEPTH health and demographic surveillance systems, Global Health Action 8 (2015). https://doi.org/10.3402/gha.v8.28298

[11] S.A. Mitchhell, W.A. Syemour and M.H. Ahmad, Ackee (Bilghia sapida): Jamaica's top fruit, Jamaican Journal of Science and Technology 33 (2008), 84-89. 
[12] O.T. Orisakeye and T.A. Olugbade, Studies on antimicrobial activities and phytochemical analysis of the plant Sterculia tragacantha lindl, Middle-East J. Sci. Res. 11(7) (2012), 924-927.

[13] O. Atolani, G.A. Olatunji and O.A. Fabiyi, Blighia Sapida: The plant and its hypoglycins: an overview, Journal of Scientific Research XXXIX(2) (2009), 15-25.

[14] AOAC, Official Methods of Analysis, Association of Official Analytical Chemists, Washington D.C., 2002.

[15] D. Person, Chemical Analysis of Foods, 7th ed., Edinburgh Churchill Living Stone, 1976.

[16] E.N. Onyeike and J.O. Osuji, Research Techniques in Biological and Chemical Sciences, Springfield Publishers Ltd., Owerri Nigeria, 2003.

[17] M. Benderitter, V. Maupoil, C. Vergely, F. Dalloz, F. Briot and L. Rochette, Studies by electron paramagnetic resonance of the important of iron in hydroxyl scavenging properties of ascorbic acid in plasma: effect of iron chelator, Fundamental \& Clinical Pharmacology 12 (1998), 510-516. https://doi.org/10.1111/j.1472-8206.1998.tb00979.x

[18] AOAC, Official Methods of Analysis, 15th ed., Association of Official Analytical Chemists: Washington, DC, 1990.

[19] R. Guisseppe, and T.M. Baratta, Antioxidant activity of selected essential oil components in two lipid model systems, Afr. J. Biotechnol. 69(2) (2000), 167-174.

https://doi.org/10.1016/S0308-8146(99)00247-2

[20] D.J. Voet, J.G. Voet and C.W. Pratt, Principles of Biochemistry, 3rd ed., John Wiley and Sons, Hoboken, New Jersey, 2008.

[21] A.O. Adetuyi and O.E. Akpambang, The nutritional value of sorgum bicolorl stem flour used for infusion drinks in Nigeria, Pak. J. Sci. Ind. Res. 49 (2005), 276-276.

[22] R.S. Jackson, Wine Science: Principles, Practice, Perception, Academic Press, California, 2000.

[23] A. Imoru, G.E. Onibi, and I.B. Osho, Nutritional and biochemical compositions of turmeric (Curcuma longa Linn) Rhizome powder - A promising animal feed additive, International Journal of Scientific \& Engineering Research 9(1) (2018).

[24] G.O. Latunde-Dada, Effect of processing on iron levels in and availability from some Nigeria vegetables, Journal of the Science of Food and Agriculture 53 (1990), 355-361. https://doi.org/10.1002/jsfa.2740530308

[25] D. Kumbarawa, G.A. Ajoku, N.M. Enwerem and D.A. Okorie, Preliminary phytochemical and anti-microbial screening of 50 medicinal plants from Nigeria, African Journal of Biotechnology 6(14) (2007), 1690-1696. 
[26] R.P. Heaney, Sodium, potassium, phosphorus, and magnesium, in: Nutrition and Bone Health, Springer, New York, 2015, pp. 379-393.

https://doi.org/10.1007/978-1-4939-2001-3_24

[27] S.A. Abdullahi and G.M. Abdullahi, Effect of boiling on the proximate, anti-nutrients and amino acid composition of raw delonixregia seeds, Niger. Food J. 23 (2005), 128132. https://doi.org/10.4314/nifoj.v23i1.33608

[28] L. S. Gills, Ethno Medical Uses of Plants in Nigeria, African Press, Benin City, 1992.

[29] A. Ikpeama, G. I. Onwuka and Chibuzo Nwankwo, Nutritional composition of tumeric (Curcuma longa) and its antimicrobial properties, International Journal of Scientific \& Engineering Research 5(10) (2014), 1085-1089.

[30] N.R. Prasad, S. Viswanathan, J.R. Devi, V. Nayak, V.C. Swetha, B.R. Archana, N. Parathasarathy and J. Rajkumar, Preliminary phytochemical screening and antimicrobial activity of Samanea saman, Journal of Medicinal Plants Research 2(10) (2008), 268-270.

[31] B.A. Bohm and M. R. Koupai-Abyazani, Flavonoids and condensed tannins from leaves of Hawaiian Vaccinium reticulatum and V. calycinum (Ericaceae), Pacific Science 48 (1994), 458-463.

[32] D.E. Okwu and C. Josiah, Evaluation of the chemical composition of two Nigerian medicinal plants, African Journal of Biotechnology 5(4) (2006), 357-361.

[33] G.A. Ayoola, H.B. Coker, S.A. Adesegun, A.A. Adepoju-Bello, K. Obaweya, E.C. Ezennia and T.O. Atangbayila, Phytochemical screening and antioxidant activities of some selected medicinal plants used for malaria therapy in southwestern Nigeria, Trop. J. Pharm. Res. 7 (2008), 1019-1024. https://doi.org/10.4314/tjpr.v7i3.14686 